\title{
КОНВЕНЦИЯ ПРОТИВ ПЫТОК
}

\author{
A.М.Я к о в л е в $^{*}$
}

Рассматривая общество как систему взаимосвязанньх социальньг институтов можно прийти к выводу, что состояние уголовной юстиции, основные характеристики ее деятельности могут послужить реальным индикатором, показателем уровня демократического развития соответствующего государства.Условием стабильного существования любого общества является обшественный порядок, осуществляемый методом государственного принуждения. Принципиальное значение, однако, имеет характер такого принуждения. И если основой основ демократии является признание неотчуждаемых прав человека и гражданина в качестве высшей социальной ценности, то именно здесь, в сфере деятельности уголовной юстиции наглядно выявляется реальньй уровень демократического развития общества и государства.

Это не случайно. Именно уголовная юстиция обладает полномочиями лишить гражданина свободы, собственности и жизни. Эти полномочия могут быть использованы для насаждения режима террора государства против своего народа (примеры общеизвестны). Социальная функция уголовной юстищии демократического государства по охране правопорядка связана с жестким, бескомпромиссным контролем за соответствием действий любых должностных лиц конституционным гарантиям прав граждан. О демократии можно судить по тому, что происходит на поверхности общественной жизни - по речам, заявлениям и заверениям, по проектам и декларащиям. Такова витрина демократии. O ее реальности следует судить по тому, что фактически происходит за закрытыми дверями - в камере для допросов, в местах задержания, предварительного заключения, в колониях и тюрьмах.

Именно здесь - за запорами и ограждениями человек остается один на один с представителями власти, с ее реальными носителями. Из всего того, что происходит (или может произойти) там, когда захлопнулась дверь, один момент вьделяется особо. Остается ли человек, подозреваемый в сожершении преступления, носителем гражданских прав, неизбежное ограничение которьх

* Профессор, доктор юридических наук, Застуженный юрист Российской Федерации, член Комитета ООН против пыток 
строго определено в законе и реально соблюдается на практике, или он превращается в бесправное сушество, отданное на милость служашим карательных органов? Расследуется преступление, подчас серьезное. Что будет предпринято: будут ли скрупулезно собираться и исследоваться объективные доказательства или у подозреваемого потребуют представить их самому, признаться? Во втором случае на сцену выступает веками существовавший прием получения подобной "царицы доказательств". Имя ему - пытка.

10 декабря 1984 года Генеральная Ассамблея ООН приняла Конвенцию против пыток и других жестоких, бесчеловечных или унижающих достоинство видов обращения и наказания. Этот документ, включаюший 33 статьи, вступил в силу 26 июня 1987 года. Конвенция была ратифицирована Советским Союзом в 1987 году. Тем самым наша страна (как и иные страны участники Конвенции) обязались предпринимать эффективные законодательные, административные и другие меры для предупреждения актов пьток на любой территории, находящейся под его юрисдикщией: Центральное место среди законодательньх мер подобного рода занимает включение в законодательство уголовной ответственности за применение пьток, определение в законе соответствующего состава самостоятельного преступления. Однако до сих пор подобное определение в утоловном законе Российской Федераџии отсутствует, пытка лишь упоминается в ряду обстоятельств, отягчаюших ответственность.

Между тем, в Конвенции содержится формулировка, даюцая исчерпывающую характеристику состава пытки. Определение "пытка" означает любое действие, которым любому лицу умышленно причиняется сильная боль или страдание, физическое или нравственное, чтобы получить от него или третьего лица сведения или признания, наказать его за действие, которое совершило оно или третье лищо или в совершении которого оно подозревается, а также запугать или принудить его или третье лищо, или по иной причине, основанной на дискриминации любого характера, когда такая боль или страдание причиняются государственным должностным лищом или иным лицом, выступающим в официальном качестве, или по их подстрекательству, или с их ведомства или молчаливого согласия.

Как видно из приведенной формулировки состав применения пыток достаточно специфичен и не сводится к составам злоупотғебления служебным положением, превышения власти, причинения телесньх поврехдений и т.д.

В решении Комитета ООН против пьток, на который возложена функция контроля за соблюдением Конвенции, принятом 
по докладу Правительства Российской Федерации на заседании в ноябре 1996 года отмечалось, что отсутствие состава преступления в применении пыток в российском законодательстве препятствует эффективной борьбе с распространенной практикой применения пыток в ходе предвария́ленного расследования, избиения заключенньх, случаев убийства подозреваемых. Пьтки, истязания и избиение задержанных остаются в большинстве случаев не наказанньми.

Опыт работы Комитета ООН против пыток показывает, что практика пыток, ее распространение зависят от ряда факторов. Наиболее очевидньм является применение пьток в ситуации, когда карательные органы используются в целях насильственного подавления политической оппозиџии - реальной или вымыпленной (опыт фашистского режима в Германии и сталинского террора в СССР). В подобньх ситуациях систематическое применение пыток становится частью государственной политики. Ясно, что страны, подписавшие Конвенцию против пыток, тем самым декларировали отказ от подобной практики.

В этих условиях продолжающаяся распространенность применения пыток в некоторьх из стран, подписавших Конвенцию, может стоять в связи с чрезвычайными условиями, существующими в таких странах, с политическим, подчас вооруженньм противостоянием. Мехду тем, часть 2 статьи 3 Конвенции содержит категорическое положение о том, что никакие исключительные обстоятельства, какими бы они не были, будь то состояние. войны или угроза войны, внутренняя политическая нестабильность или любое другое чрезвычайное положение, не могут служить оправданием пьток.

Современное неудовлетворительное положение с выполнением требований Конвенции против пьток в России связано с иньм, но не менее значительным фактором - несовершенством правового механизма защиты прав человека, попадающего в сферу деятельности уголовной юстиции, явно неудовлетворительным контролем за соблюдением таких прав, с неэффективностью реагирования на факты применения пыток, несовершенством, слабостью системы обжалования подобного рода преступньх действий долхностньх лиц, государственньх структур, которая должна обеспечивать своевременное выявление, быстрое и эффективное реагирование на факты применения пыток.

В статье 16 Конвенции содержится обязанность государств участников Конвенции предотвращать другие акты жестокого, бесчеловечного или унижающего достоинство обращения и наказания. Между тем, как отмечается в отчете специального 
докладчика Комиссии ООН по правам человека Найджела Родли, посетившего Россию в 1994 году, условия содержания заключенных в России (особенно в СИЗО) являются "пыточными”. Определенный шаг в сторону выправления такого положения делается в настояшее время в форме передачи мест заключения в ведение Министерства юстиции.

В этот год, объявленный Организацией Объединенньх Наций годом прав человека, в год, когда мы отмечаем 50-летие Всеобщей декларации прав человека, необходима мобилизация законодательной, исполнительной и судебной власти, сознательной общественности, правозашитньх организаций для того, чтобы необходимые законодательные, организационные, просветительные меры создали перелом к лучшему в той области зашиты прав человека и гражданина, где их нарушения наиболее жестоки и бесчеловечны - в сфере деятельности органов правопорядка и уголовной юстиции. Успех подобных усилий послужит надежным показателем реальности нашего продвижения к свободному демократическому порядку, где эффективность борьбы с преступностњю идет рука об руку с эффективной зашитой наших гражданских конституционньх прав.

\section{ДОПОЛНИТЕЛЬНЫЙ ПРОТОКОЛ О НЕМЕЖДУНАРОДНОМ ВООРУЖЕННОМ КОНФЛИКТЕ 1997 Г. И ПРОБЛЕМА БЕЖЕНЦЕВ}

\section{И.П. Б л и щ е н к}

Немеждународный вооруженный конфликт является, как правило, результатом перерастания внутренней напряженности к широкомасштабному нарушению прав человека. И в этой связи немеждународный вооруженный конфликт является как бы высшей точкой нарушения прав и свобод человека. В России таким примером могут служить чеченские события, когда гражданская война поставила ряд вопросов нарушения прав и свобод человека. В данном случае юәчь шла не только

* Академик, профессор, доктор юридических наук, заслуженный деятель науки Российской Федерации, лауреат Международной премии имени Гуго Гроция. 